\title{
Muscarinic Agonists Activate an Inwardly Rectifying Potassium Conductance in Medial Pontine Reticular Formation Neurons of the Rat in vitro
}

\author{
U. Gerber, D. R. Stevens, R. W. McCarley, and R. W. Greene \\ Harvard Medical School and Veterans Administration Medical Center, Brockton, Massachusetts 02401
}

\begin{abstract}
Intracellular recordings were obtained from neurons in pontine reticular formation slices of the rat to characterize a cholinergic-gated increase in conductance. The conductance increase was associated with a hyperpolarization of the membrane potential and with an outward current under voltage-clamp conditions. Current-voltage relations and potassium substitution experiments indicated mediation by a change in permeability, primarily to potassium. This potassium conductance exhibited inward rectification at membrane potentials negative to resting potential, a novel finding for cholinergic actions in CNS neurons. Further characterization of this inwardly rectifying potassium conductance revealed marked sensitivity to low concentrations of barium. Cholinergically evoked currents were relatively unaffected by the presence of extracellular cesium. Cholinergic effects persisted in TTX. The outward currents elicited by carbachol or methacholine were blocked only by high concentrations of pirenzepine, a selective antagonist of the $M$, muscarinic receptor. The interaction between these agents is quantitatively consistent with cholinergic action at postsynaptic muscarinic receptors of the non- $M_{1}$ subtype.
\end{abstract}

A neuronal circuit that includes the cholinergic efferents from the laterodorsal and pedunculopontine tegmental nuclei to the medial pontine reticular formation (mPRF) may be integral to the generation and maintenance of rapid eye movement (REM) sleep (Steriade and McCarley, 1990). Knowledge of the mechanisms of cholinergic action at the cellular level in the mPRF is a necessary first step in the clarification of the function of this circuit.

The predominant response to ACh acting at muscarinic receptors in the CNS is a depolarization associated with a decrease in potassium conductance (McCormick, 1989), and a similar depolarizing response to cholinergic agents has been observed in the majority of neurons in the mPRF (Greene et al., 1989). However, neurons in the parabrachial nucleus and the medial and lateral geniculate nuclei of the thalamus have been reported to hyperpolarize upon muscarinic activation as a result of an increase in potassium conductance (Egan and North, 1986; McCormick and Prince, 1986; Christie and North, 1988; McCor-

\footnotetext{
Received Mar. 12, 1991; revised July 9, 1991; accepted July 17, 1991.

We thank Dr. S. Birnstiel for help with the barium sensitivity experiments and Dr. S. Winston for excellent technical assistance. The research is supported by the U.S. Department of Veterans Affairs.

Correspondence should be addressed to R. W. Greene, Neuroscience Lab 151C, Veterans Administration Medical Center, Brockton, MA 02401.

Copyright (C) 1991 Society for Neuroscience $0270-6474 / 91 / 113861-07 \$ 05.00 / 0$
}

mick and Pape, 1988). In the mPRF, approximately one-fourth of the cells hyperpolarized in response to cholinergic agonists (Greene et al., 1989). The goal of the present investigation was to characterize the conductance responsible for this hyperpolarization. At least five types of potassium conductances in the CNS are known to be enhanced by neurotransmitters, including a non-voltage-sensitive conductance (Gerber et al., 1989b), the A-conductance (Atkins et al., 1990), the M-conductance (Jacquin et al., 1988), an inwardly rectifying conductance (Williams et al., 1988b), and a voltage-insensitive calcium-dependent potassium conductance (Haas and Greene, 1984). We here present data indicating that an inwardly rectifying potassium conductance in $\mathrm{MPRF}$ is enhanced by activation of a cholinergic receptor, an observation not previously reported for CNS neurons. This conductance appears similar in both voltage and pharmacological sensitivity to the agonist-gated inward rectifier described in other mammalian preparations (North, 1989).

A preliminary report of some of this work has been published previously (Greene et al., 1989).

\section{Materials and Methods}

Methods of preparation and maintenance of slices of medial pontine reticular formation have been described previously (Greene et al., 1986; Gerber et al., 1989a). Coronal brainstem slices containing the medial pontine reticular formation were prepared from young Sprague-Dawley or Long-Evans rats (8-20 d) following decapitation under halothane anesthesia. Slices were fully submerged in perfusion medium containing (in $\mathrm{mM}$ ) $\mathrm{NaCl} 124, \mathrm{KCl} 3.75, \mathrm{KH}_{2} \mathrm{PO}_{4} 1.25, \mathrm{NaHCO}_{3} 26$, glucose 10 , $\mathrm{CaCl}_{2} 2.5, \mathrm{MgCl}_{2} 1.4$, which was kept at $30^{\circ} \mathrm{C}$ at a flow rate of $1.5 \mathrm{mV}$ min (dead space plus chamber volume equals $1.2 \mathrm{ml}$ ). Intracellular recordings were made with glass microelectrodes filled with $2 \mathrm{M} \mathrm{KCl}$ (resistance, 50-90 Ms) for recording of membrane potential or for voltage-clamp recordings in the sample and hold single-electrode mode with an Axoclamp 2A amplifier (Axon Instruments, Burlingame, CA). Head stage output was constantly monitored to ensure adequate settling time. Drugs were applied in known concentrations to the perfusion medium or by pressure ejection through a micropipette with tip diameter of 10 $50 \mu \mathrm{m}$ filled with a $1 \mathrm{~mm}$ solution of carbachol dissolved in perfusate.

Duration and pressure parameters for drug ejection through puffer pipettes were chosen to evoke responses approximating those observed with $1 \mu \mathrm{M}$ bath application of carbachol. Drugs were obtained from Sigma. All pooled data are expressed as the mean \pm 1 unit standard deviation.

\section{Results}

The cholinergic agonist carbachol was applied to 96 neurons of the $\mathrm{mPRF}$ formation during stable intracellular recordings (resting potential, $-61 \pm 5 \mathrm{mV}$; input resistance, $81 \pm 34 \mathrm{M} \Omega$ ). Bath application $(0.5-5 \mu \mathrm{M})$ or puffer ejection of carbachol depolarized 70 cells $(73 \%)$, hyperpolarized 20 cells $(21 \%)$, caused a biphasic hyperpolarization-depolarization response in 3 cells, 


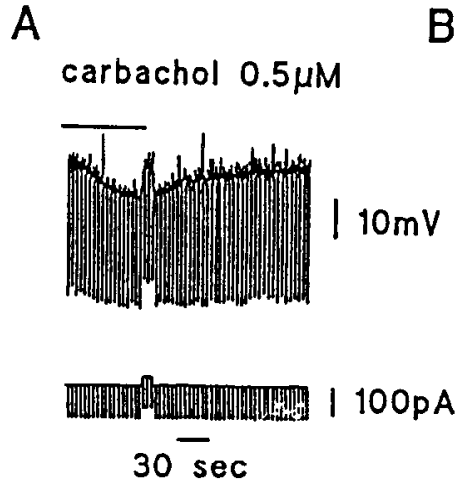

D
B

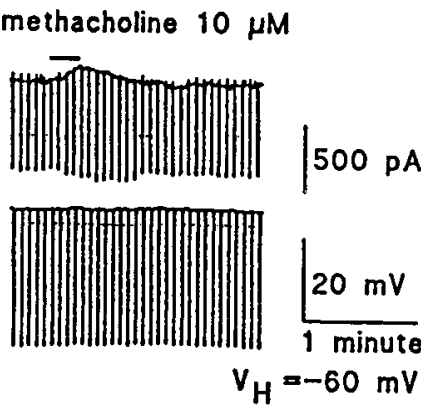

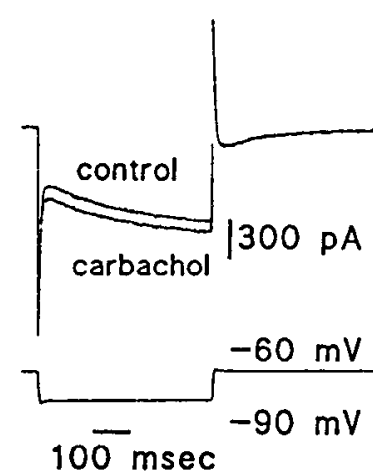

$E$

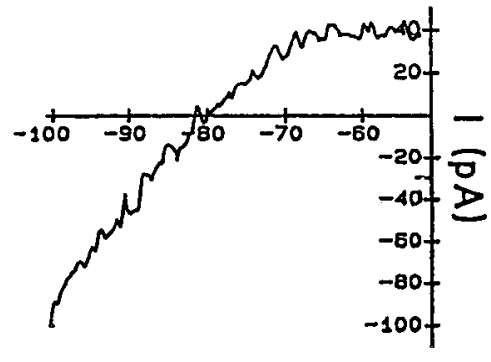

$V_{m}(m V)$

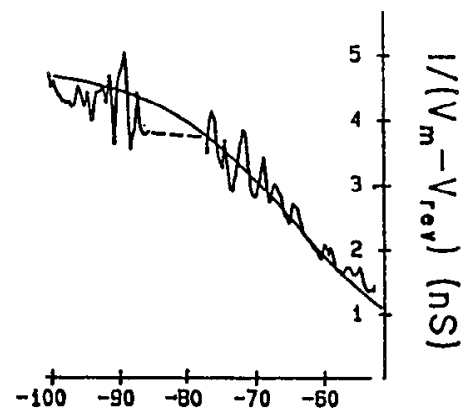

$V_{m}(m V)$

Figure 1. Muscarinic agonists increase membrane conductance. $A$, A voltage record shows that bath application of carbachol increases membrane conductance and results in hyperpolarization of membrane potential. Current pulses (400 msec duration) were injected to assess membrane conductance, and membrane potential was briefly repolariced to compensate for possible contributions from voltage-sensitive intrinsic conductances. $B$, Application of methacholine ( $10 \mu \mathrm{M} ; 0.5 \mu \mathrm{M}$ TTX present) to a cell voltage clamped at $-60 \mathrm{mV}$ and stepped to $-90 \mathrm{mV}$ with $500 \mathrm{msec}$ voltage command pulses causes an outward current associated with an increase in membrane conductance. $C$, The carbachol-sensitive conductance activates instantaneously, while there is no effect on the time-dependent inward current relaxation. A control trace is superimposed on a trace during peak carbachol effect at an expanded time base. $D$, An $I / V$ plot of carbachol-evoked current shows inward rectification. Note the increased slope conductance at hyperpolarized membrane potentials. The plot was constructed by subtracting the whole-cell current responses to voltage ramp commands in control conditions from the whole-cell current obtained in the presence of carbachol. $E$, Plot of conductance versus voltage obtained by dividing the data in $D$ by the driving force. Membrane conductance diminishes as membrane potential is depolarized. The data are fitted to a curve derived from the Boltzmann equation: $G_{\mathrm{K}}=G_{\mathrm{K}(\max )} /\left\{1+\exp \left[\left(V-V_{\mathrm{y}_{2}}\right) / \mathrm{k}\right]\right\}$ (solid line). $G_{\mathrm{K}(\max )}$ was estimated to be $5 \mathrm{nS}$ for the data in $E$. The $k$ value (11.6) was determined as the slope of a least-squares fit to the conductance data points measured in $E$ and graphed semilogarithmically against voltage, $V=k\left\{\ln \left(G_{\max } / G\right)-1\right\}+V_{1 / 2}$. These $k$ and $G_{\max }$ values provide a good fit, accounting for $93 \%$ of the data variance.

and had no effect on 3 cells. The conductance and receptors mediating the hyperpolarizing cholinergic response are the subject of this communication.

We have previously reported that MPRF neurons can be classified into two principal types based on the presence or absence of a low-threshold calcium spike that underlies burst firing at hyperpolarized membrane potentials (Greene et al., 1986; Gerber et al., 1989a). In the present sample, $37 \%$ of the cells exhibited a low-threshold burst. Nine of the 20 neurons $(45 \%)$ that were hyperpolarized by carbachol exhibited a low-threshold burst, while the remaining 11 cells were of the non-burst type. $\chi^{2}$ analysis showed no statistically significant association between burst presence and muscarinic hyperpolarization $(P>$ $0.25)$.

\section{Potassium conductance is increased by carbachol}

Figure 1 shows examples of cholinergic agonist-induced increases in neuronal membrane conductance resulting in hyper- polarization of the resting potential $(A)$. Hyperpolarizations associated with treatment with carbachol $(0.5-1.0 \mu \mathrm{M} ; n=11)$ or methacholine (10 $\mu \mathrm{M} ; n=2)$ were associated with an outward current $(B)$. Carbachol was applied via puffer on 9 cells and bath applied in 11 cells $(0.5$ or $1 \mu \mathrm{M})$. The average decrease in input resistance was $18 \pm 6 \mathrm{M} \Omega(n=17)$, altering resting membrane potential by $-6 \pm 2 \mathrm{mV}$. Figure $1 A$ illustrates the measurement of the change in input resistance; carbachol was applied by bath and, for input resistance measurement, membrane potential was briefly repolarized to the control voltage (between -60 and -65 $\mathrm{mV}$ ) to control for effects of voltage-dependent intrinsic membrane currents. Figure $1 B$ illustrates, in another neuron during voltage clamp, the effects on current of bath application of methacholine $(10 \mu \mathrm{M})$ following TTX $(0.5 \mu \mathrm{M})$ exposure.

There was no apparent action of muscarinic agonists on timedependent inward rectification. When the cell was held at -60 $\mathrm{mV}$, carbachol elicited $80 \mathrm{pA}$ of outward current. The increase in current response to the $400 \mathrm{msec}$ voltage command pulses 

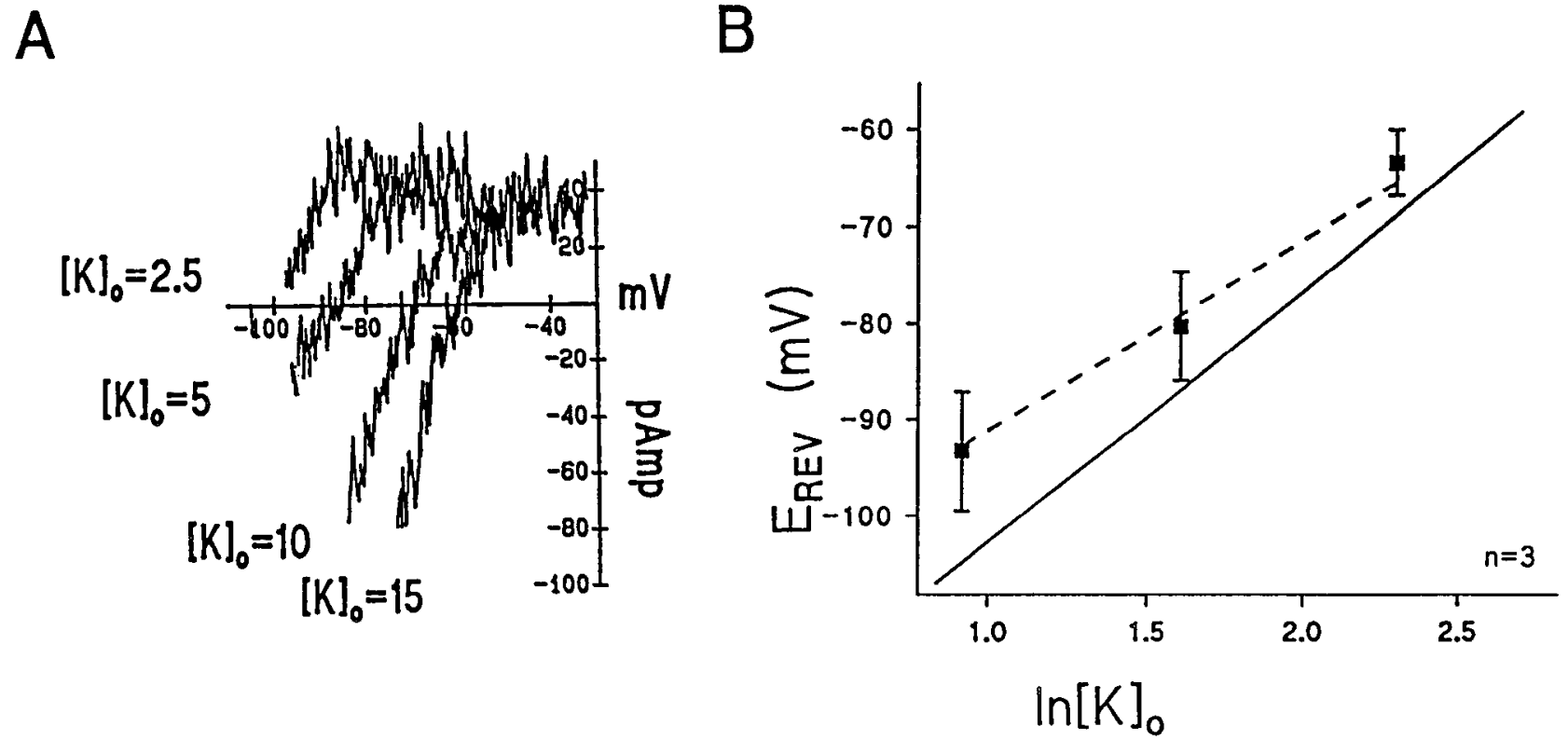

Figure 2. A. The current-voltage curves for carbachol-evoked current as determined by voltage ramps at different concentrations of potassium. The reversal potential as well as the inflection reflecting inward rectification is shifted in a Nernstian fashion with changes in extracellular potassium. $B$, Plot of pooled data for the reversal potential at three different potassium concentrations. The solid line indicates the relationship of reversal potential to $[K]$ for a pure potassium conductance. The slight deviation from this line may reflect a small contribution from another ion. The broken line indicates the reversal potential for a potassium channel with partial permeability to sodium ions $\left(P_{\mathrm{Na}} / P_{\mathrm{K}}=1 / 100\right)$. Error bars represent 1 unit SD.

from -60 to $-90 \mathrm{mV}$ during carbachol exposure was immediately observable following the capacitative transients as shown in Figure $1 C$. Superimposition of current traces in control and during maximal carbachol action by subtracting the $100 \mathrm{pA}$ of carbachol-evoked outward current (measured at the holding potential) demonstrated that carbachol was without effect on a time-dependent inward current relaxation, corresponding to " $Q$ " current or " $\mathrm{H}$ " current (Halliwell and Adams, 1982; Mayer and Westbrook, 1983; Bobker and Williams, 1989; Pape and McCormick, 1989).

In nine neurons, current-voltage plots were generated using a slow voltage-command ramp protocol during control conditions and in the presence of carbachol; voltage was changed at the rate of $2.5 \mathrm{mV} / \mathrm{sec}$ between -100 and $-40 \mathrm{mV}$. By digitally subtracting the control from the carbachol current trace, the carbachol-sensitive current was determined (Fig. 1D).

The carbachol-evoked current exhibited inward rectification at potentials negative to resting membrane potential as shown in Figures $1 D, 2 A$, and 3 . The relationship between the chord conductance [computed at $50 \mu \mathrm{V}$ increments as $I /\left[\left(V_{m}-V_{\text {reversal }}\right)\right]$ and voltage is plotted in Figure $1 E$. Conductance rapidly decreased at membrane potentials more depolarized than resting potential. (At $V_{m}$ near $V_{\text {reversal }}$ chord conductance is undefined $(\rightarrow \infty)$, and consequently we have used a broken line to indicate an extrapolated conductance in this region.)

The conductance was fit by a Boltzmann expression:

$$
G_{\mathrm{K}}=G_{\mathrm{K}(\max )} /\left\{1+\exp \left[\left(V-V_{1 / 2}\right) / k\right]\right\},
$$

where $G_{\mathrm{K}(\max )}$ is the maximum potassium conductance, $V_{1 / 2}$ is the voltage at which $G_{\mathrm{K}}$ is half-maximal, and $k$ defines the steepness of the curve. The empirically derived values for the MPRF carbachol-activated potassium conductance at $[K]_{o}=5 \mathrm{~mm}(n$ $=3$ cells) were $V_{1 / 2}=-65.8 \pm 2.4 \mathrm{mV}$ and $k=9.9 \pm 1.2 \mathrm{mV}$.

The inwardly rectifying properties of this conductance were maintained during changes in external potassium concentration, and $V_{1 / 2}$ varied in the same direction as the reversal potential, as reported for other inward rectifiers (Hagiwara and Takahashi, 1974) (Fig. 2A). The reversal potential of the response was -80 $\pm 4.5 \mathrm{mV}$ in $[K]_{o}$ of $5 \mathrm{~mm}$. Assuming a $[K]_{i}$ of $140 \mathrm{~mm}$ (Alger and Nicoll, 1980), the Nernst equation predicts a reversal potential of $-87 \mathrm{mV}$ for a response mediated by a selective increase in potassium permeability. Thus, the result obtained is consistent with a change primarily in a $\mathrm{K}^{+}$conductance. The reversal potential for this response varied with external potassium. There was a slight positive deviation in the data points from the theoretical line of reversal potential for a response mediated by a purely potassium-selective conductance (Fig. $2 B$ ).

\section{Characterization of potassium conductance}

The sensitivity of the carbachol-activated conductance to ions that specifically block inwardly rectifying potassium channels was examined. Low concentrations of barium have been shown to be selective for potassium inward rectifier currents (Standen and Stanfield, 1978; Osmanovic and Shefner, 1987; Surprenant and North, 1988; Williams ct al., 1988b). Figure $3 A$ shows that barium $(100 \mu \mathrm{M})$ reversibly blocked the inwardly rectifying conductance evoked by application of carbachol $(n=3)$. An additional inwardly rectifying conductance prevalent in vertebrate CNS neurons is responsible for " $\mathrm{H}$ " or " $\mathrm{Q}$ " current $\left(I_{H}\right)$. This current, carried by potassium and sodium ions, has been shown to be modulated by neurotransmitters (Bobker and Williams, 1989; Pape and McCormick, 1989) and is selectively blocked by external cesium but not barium (Halliwell and Adams, 1982; Mayer and Westbrook, 1983). Figure $3 B$ compares the carbachol-sensitive conductance with the cesium-sensitive conductance $(n=5)$. The current blocked by cesium was typical for $I_{H}$ in that it activated only at relatively hyperpolarized potentials, did not reverse polarity, and approached a reversal potential more depolarized than expected for a pure potassium conductance. In contrast, the carbachol-evoked current reversed 


\section{Carbachol evoked current}

A

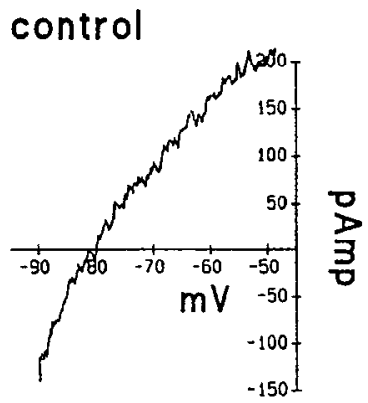

Figure 3. The sensitivity of carbachol-evoked current to barium and cesium. $A$, Barium reversibly blocks carbachol-elicited current. $B a$, Comparison of carbachol-sensitive current and cesium-sensitive current (obtained by subtraction of the whole-cell current in the presence of cesium from the control current). Although both currents show inward rectification, they appcar to result from different conductances. $B b$, Ramp responses illustrating the effect of cesium on carbachol-evoked current.
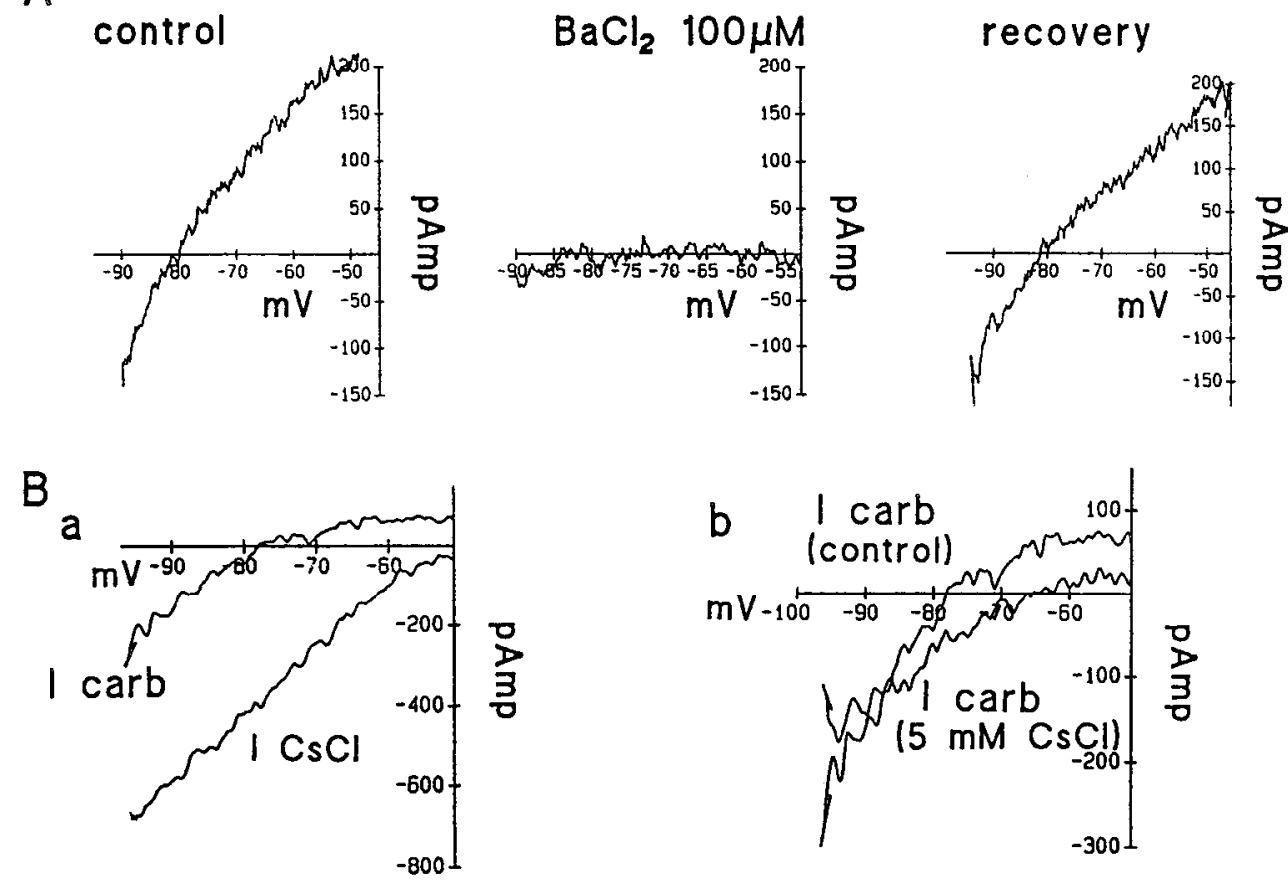

polarity at approximately $-80 \mathrm{mV}$ and was not affected by 1 mM cesium at membrane potentials positive to the reversal potential. At more negative potentials, carbachol-evoked current was reduced (data not shown), similar to cesium effects on other inward rectifier potassium currents (see Discussion). In the presence of $5 \mathrm{~mm}$ cesium, the reversal potential was depolarized by $9.2 \pm 2.1 \mathrm{mV}(n=3)$, but the slope of the $I / V$ curve was not affected at potentials positive to $-80 \mathrm{mV}$ (Fig. $3 B b$ ).

The potassium conductance is activated via non- $M_{\text {, }}$ muscarinic receptors

Pirenzepine has been used in a number of preparations to distinguish between muscarinic $M_{1}$ and non- $M_{1}$ binding sites (Hammer et al., 1980), and more recently, the neuronal biochemical (McKinney et al., 1989b) and electrophysiological (North et al., 1985; Egan and North, 1986; Marrion et al., 1989) effects have been correlated with these specific sites. The dissociation constant, $K_{i}$, for pirenzepine at the cortical $\mathbf{M}_{1}$ receptor was reported as $6.99 \mathrm{nM}$ and, at the brainstem non- $M_{1}$ receptor, as $219 \mathrm{nM}$ (McKinney et al., 1989a). The agonist carbachol was also reported to show selectivity as follows: the dissociation constant, $K_{D}$, for cortical $\mathrm{M}_{1}$ receptors was $0.32 \mu \mathrm{M}$ (Potter and Ferrendelli, 1989), and for pontine reticular formation non- $M_{1}$ receptors, $1.4 \mu \mathrm{M}$ (Cortes and Palacios, 1986). The muscarinic agonist methacholine has similar $K_{D}$ values: cortical $\mathrm{M}_{1} K_{D}$ was reported as $0.47 \mu \mathrm{M}$ (Potter and Ferrendelli, 1989), and heart $\mathrm{M}_{2} K_{D}$ was reported as $0.25 \mu \mathrm{M}$ (Fuder and Jung, 1985). To provide a quantitative measure of the agonist-antagonist interaction, the ratio of the response to carbachol in the presence of pirenzepine $\left(R_{\mathrm{p} z}\right)$ to the response to the same dose of carbachol without pirenzepine $\left(R_{c}\right)$ was experimentally determined in the mPRF. Based on the mass action law for receptor kinetics, the equation describing this ratio is

$$
R_{\mathrm{p} z} / R_{r}=\left\{K_{n}+[\mathrm{Carb}]\right\} /\left\{K_{n}\left(1+[\mathrm{Pz}] / K_{i}\right)+[\mathrm{Carb}]\right\},
$$

where [Carb] and $[\mathrm{Pz}]$ are the concentration of carbachol and pirenzepine, respectively. The theoretical values (based on the $K_{D}$ and $K_{i}$ values mentioned above) for $R_{\mathrm{pz}} / R_{c}$ are 0.07 at the $\mathrm{M}_{1}$ receptor and 0.48 at the non- $\mathrm{M}_{1}$ receptor with $[\mathrm{Carb}]=1$ $\mu \mathrm{M}$ and $[\mathrm{Pz}]=0.4 \mu \mathrm{M}$. We observed an average ratio of $0.49 \pm$ $0.05(n=3)$. Expected ratios employing pirenzepine $(0.4 \mu \mathrm{M})$ and methacholine $(10 \mu \mathrm{M})$ are 0.28 at $\mathrm{M}_{1}$ receptors and 0.73 at $M_{2}$ receptors. The observed ratio was 0.67 (Fig. 4).

$\mathrm{The} \mathrm{IC}_{50}$ for pirenzepine, estimated from a best fit of a logistic function to a pirenzepine inhibition curve constructed from pooled data $(n=5$; carbachol at $1 \mu \mathrm{M}$ in the bath or an equivalent response to puffer application), was $670 \mathrm{nM}, 2$ orders of magnitude greater than that reported for $M_{1}$ receptors (Fig. 4).

\section{Discussion}

We have presented data demonstrating that postsynaptic muscarinic receptors mediate an increase in an inwardly rectifying potassium conductance in $21 \%$ of the neurons in the mPRF. Modulation of an inwardly rectifying potassium conductance in mammalian CNS by neurotransmitter agonists has been shown for 5-HT (Andrade and Nicoll, 1987; Colino and Halliwell, 1987; Williams et al., 1988a; Yakel et al., 1988; North and Uchimura, 1989), baclofen (Gähwiler and Brown, 1985), opioids (North et al., 1987; Williams et al., 1988b), noradrenaline (Williams et al., 1985), somatostatin (Inoue et al., 1988), adenosine (Trussel and Jackson, 1985), and substance P (Stanfield et al., 1985).

Cholinergic gating of an inwardly rectifying potassium conductance in CNS has not been previously demonstrated. Christie and North (1988) have suggested that the muscarinic receptor- 
A

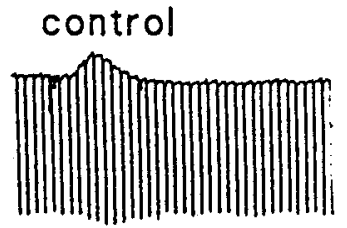

Mch $10 \mu \mathrm{M}$

C

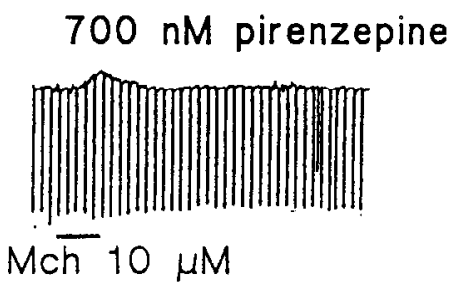

B

$400 \mathrm{nM}$ pirenzepine

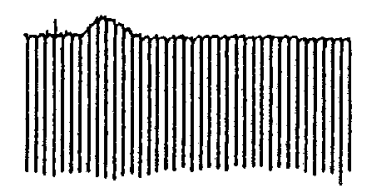

$\mathrm{Mch} 10 \mu \mathrm{M}$
D $1000 \mathrm{nM}$ pirenzepine

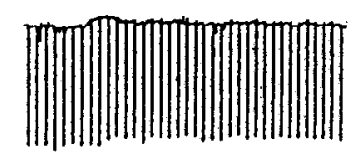

Mch $10 \mu \mathrm{M}$

$$
V_{H}=-65 \mathrm{mV} \quad \frac{200 \mathrm{pA}}{2 \text { minutes }}
$$

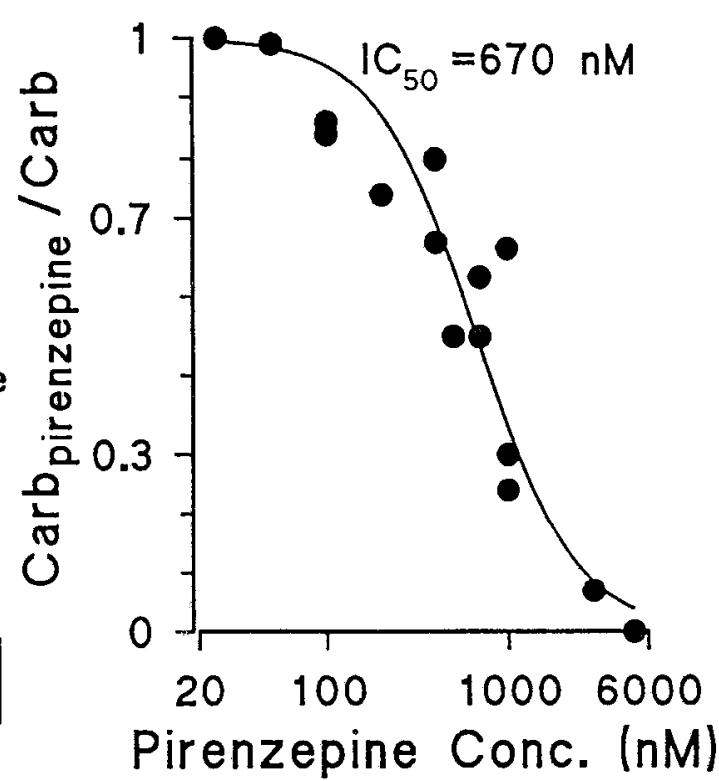

Figure 4. Effect of pirenzepine, an $\mathrm{M}_{1}$ muscarinic antagonist, on the cholinergic response. Bath application of methacholine (10 $\left.\mu \mathrm{M}\right)$ evokes outward currents in a cell voltage clamped at $-60 \mathrm{mV} . A, \mathrm{~A}$ control response to methacholine. $B-D$, Responses to identical applications of methacholine in the presence of increasing concentrations of pirenzepine. The log-concentration/response curve for pirenzepine inhibition of carbachol currents (right panel; results pooled from five neurons) indicates the concentration dependence of pirenzepine depression of carbachol responses. The sigmoid curve was fit using a logistic equation with a $\mathrm{IC}_{50}$ of $670 \mathrm{nM}$.

activated hyperpolarization in rat parabrachial neurons is mediated by an inwardly rcctifying potassium conductance since it is occluded during activation of the inwardly rectifying $\mu$-opioid response. Muscarinic agonists elicit a potassium conductance in cardiac pacemaker cells (Noma and Trautwein, 1978; Sakmann et al., 1983) that has properties similar to the inward rectifier described in the present study.

The agonist-gated inward rectifier has a $V_{1 / 2}$ near $-65 \mathrm{mV}$ (Stanfield et al., 1985; Williams et al., 1988b; Tatsumi et al., 1990). The close similarity of the previously described agonistgated conductance with the muscarinic-gated conductance in the present study provides further evidence that different receptors can be coupled to the same conductance (Swann and Carpenter, 1975), with specificity occurring in the particular kind(s) of receptor found in various neuronal classes (North, 1989). The recent results reported by Selyanko et al. (1990) working on bullfrog sympathetic ganglion cells indicate that both a muscarinic and an adrencrgic receptor gate the same potassium inward rectifier in C-cells.

5-HT acting at 5-HT $\mathrm{HT}_{1}$ receptors and noradrenaline at $\alpha_{2}$-receptors also increase a potassium conductance in mPRF cells (Gerber et al., 1989c; Stevens et al., 1991). The conductance activated by 5 -HT was not inwardly rectifying. The adrenergically coupled potassium conductance displayed inward rectification, but further experiments will be required to determine whether muscarinic receptors gate this same conductance in mPRF

The voltage sensitivity of the inward rectifier current can be attributed to the conductance properties of the component single channels. They pass current better in the inward direction (Sakmann and Trube, 1984; Matsuda and Stanfield, 1990) because, at least in some cases, of a blockade of the outward current by internal magnesium (Vanderberg, 1987). Other mechanisms can lead to inward rectification that do not involve inward rectifier channels. The channel population can be voltage gated, being in an active state at hyperpolarized potentials and an inactive state at depolarized potentials. This may occur in the channels mediating $I_{H}$ (Halliwell and Adams, 1982; Mayer and Westbrook, 1983; Bobker and Williams, 1989; Pape and McCormick, 1989). Alternatively, there may be a simulation of inward rectification due to the agonist's activating an inward current at depolarized potentials (Freschi and Livengood, 1989) in addition to a non-voltage-sensitive potassium current, resulting in less net outward current at the depolarized potentials. The fact that the cholinergic inward rectification shifted in a manner parallel with potassium reversal potential is most consistent with inwardly rectifying channels. Further evidence identifying this potassium conductance as a true inward rectifier is provided by the barium blockade experiment. The low concentration of barium employed here has been shown to block an inwardly rectifying potassium conductance in other neurons (Osmanovic and Shefner, 1987; Surprenant and North, 1988; Williams et al., 1988a,b). Finally, as opposed to the time-dependent inward current due to the " $\mathrm{H}$ " conductance that is not affected by carbachol in mPRF, the conductance increase due to carbachol exhibited rapid kinetics, typical of the potassium inward rectifier (Sakmann and Trube, 1984; Inoue et al., 1988).

The effects of cesium appear more complex. At lower concentrations, the most prominent effect is the antagonism of the inward current as previously reported (Hagiwara et al., 1976; Gay and Standen, 1977; Mihara et al., 1987; Inoue et al., 1988; Williams et al., 1988a,b). At higher concentrations, an additional effect, a shift in the reversal potential, was observed. However, as with the lower concentration, slope conductance positive to the reversal potential was unaffected. This may be consistent with a low partial permeability to cesium resulting 
in an additional inward current in the presence of higher external cesium ion concentrations.

Based on the experiments with the muscarinic antagonist pirenzepine and the agonists carbachol and methacholine, the receptors mediating the increase in potassium conductance are of the non- $M_{1}$ subtype. It has not been possible to obtain sufficient data to graph Schild plots in order to determine the antagonist dissociation constant, $K_{B}$, for the receptor. However, given the relative selectivity of the agents employed, determination of the electrophysiologically relevant receptor as a non$M_{1}$ subtype appears reasonable. Furthermore, our findings are in agreement with autoradiographic data (Mash and Potter, 1986), binding studies (Lazareno and Roberts, 1989), in situ hybridization experiments that localized mRNA for the $\mathrm{M}_{2}$ and $M_{3}$ gene product in the pons (Buckley et al., 1988), and behavioral results (Velazquez-Moctezuma et al., 1989), all of which are consistent with the presence of predominantly non- $M_{1}$ receptors in this brainstem region.

At the cellular level, the functional implication of an increased inwardly rectifying potassium conductance is that excitability is depressed in a nonlinear manner. For a given amount of cholinergic activation, the increase in conductance will be relatively greater at more hyperpolarized levels and thus exert a relatively greater depressant effect on excitatory input. Similarly, excitatory input will have an increased tendency toward an allor-nothing effect.

A cholinergically induced depolarization of the pool of $\mathrm{mPRF}$ neurons appears to be crucial in the initiation and maintenance of the REM sleep behavioral state (Steriade and McCarley, 1990). The best pharmacological model for REM sleep is achieved with the microinjection of muscarinic (cholinergic) agonists into the mPRF of behaving animals (Baghdoyan et al., 1985). Most mPRF neurons are excited during natural and chemically induced REM. However, it is not unreasonable to expect a subpopulation of mPRF cells, perhaps the descending reticulospinal neurons important in motor activity, to be inhibited during REM sleep. Further work characterizing anatomical projection patterns will be useful in defining the behaviorally related function of the subset of neurons that exhibit muscarinic hyperpolarization.

\section{References}

Alger BE, Nicoll RA (1980) Epileptiform burst after-hyperpolarization: a calcium-dependent potassium potential in hippocampal CA1 pyramidal cells. Science 210:1122-1124.

Andrade R, Nicoll RA (1987) Pharmacologically distinct actions of serotonin on single pyramidal neurones of the rat hippocampus recorded in vitro. J Physiol (Lond) 394:99-124.

Atkins PT, Surmeier DJ, Kitai ST (1990) Muscarinic modulation of a transient $\mathrm{K}^{+}$conductance in rat neostriatal neurons. Nature 344 : $240-242$.

Baghdoyan HG, McCarley RW, Hobson JA (1985) Cholinergic manipulation of brainstem reticular systems: effects on desynchronized sleep generation. In: Sleep: neurotransmitters and neuromodulators (Waquier A, Monti J, Gaillard JP, Radulovacki M, eds), pp 15-27. New York: Raven.

Bobker DH, Williams JT (1989) Serotonin augments the cationic current $I_{h}$ in central neurons. Neuron 2:1535-1540.

Buckley NJ, Bonner TI, Brann MR (1988) Localization of a family of muscarinic receptor $m$ RNAs in rat brain. Neurosci 8:4646-4652.

Christie MJ, North RA (1988) Agonists at $\mu$-opioid, $\mathbf{M}_{2}$-muscarinic and $\mathrm{GABA}_{\mathrm{B}}$-receptors increase the same potassium conductance in rat lateral parabrachial neurones. Br J Pharmacol 95:896-902.

Colino A, Halliwell JV (1987) Differential modulation of three separate $\mathrm{K}$-conductances in hippocampal CAl neurons by serotonin. Nature 328:73-77.

Cortes R, Palacios J (1986) Muscarinic cholinergic receptor subtypes in the rat brain. I. Quantitative autoradiographic studies. Brain Res 362:227-238.

Egan TM, North AR (1986) Acetylcholine hyperpolarizes central neurones by acting on an $\mathbf{M}_{2}$-muscarinic receptor. Nature 319:405-407.

Freschi JE, Livengood DR (1989) Membrane current underlying cholinergic excitation of motoneurons in lobster cardiac ganglion. J Neurophysiol 62:984-995.

Fuder H, Jung B (1985) Affinity and efficacy of racemic, (+)- and (-)methacholine in muscarinic inhibition of $\left[\mathrm{H}^{3}\right]$-noradrenaline release. Br J Pharmacol 84:477-487.

Gähwiler BH, Brown DA (1985) GABA $_{\mathrm{b}}$-receptor-activated $\mathrm{K}^{+}$current in voltage-clamped CA3 pyramidal cells in hippocampal cultures. Proc Natl Acad Sci USA 82:1558-1560.

Gay L, Standen PR (1977) $\mathrm{Cs}^{+}$causes a voltage-dependent block of inward K currents in resting skeletal muscle fibres. Nature 267:169170.

Gerber U, Greene RW, McCarley RW (1989a) Repetitive firing properties of medial pontine reticular formation neurones of the rat recorded in vitro. J Physiol (Lond) 410:533-560.

Gerber U, Greene RW, Haas HL, Stevens DR (1989b) Characterization of inhibition mediated by adenosine in the hippocampus of the rat in vitro. J Physiol (Lond) 417:567-578.

Gerber U, Greene RW, Haas HL, McCarley RW (1989c) Receptor characterization of adrenergic effects in the medial pontine reticular formation in vitro. Soc Neurosci Abstr 15:194.

Greene RW, Haas HL, McCarley RW (1986) A low threshold calcium spike mediates firing pattern alterations in pontine reticular neurons. Science 234:738-740.

Greene RW, Gerber U, McCarley RW (1989) Cholinergic activation of medial pontine reticular formation neurons in vitro. Brain Res 476: 154-159.

Haas HL, Greene RW (1984) Adenosine enhances afterhyperpolarization and accommodation in hippocampal pyramidal cells. Pfluegers Arch 402:244-247.

Hagiwara S, Takahashi $K$ (1974) The anomalous rectification and cation selectivity of the membrane of a starfish egg cell. J Membr Biol 18:61-80.

Hagiwara S, Miyazaki S, Rosenthal P (1976) Potassium current and the effect of cesium on this current during anomalous rectification of the egg cell membrane of a starfish. J Gen Physiol 67:621-638.

Halliwell JV, Adams PR (1982) Voltage-clamp analysis of muscarinic excitation in hippocampal neurons. Brain Res 250:71-92.

Hammer R, Berrie CP, Birdsall NJM, Burgen ASV, Hulme EC (1980) Pirenzepine distinguishes between different subclasses of muscarinic receptors. Nature 283:90-92.

Inoue M, Nakajima S, Nakajima Y (1988) Somatostatin induces an inward rectification in rat locus coeruleus neurones through a pertussis toxin-sensitive mechanism. J Physiol (Lond) 407:177-198.

Jacquin T, Champagnat J, Madamba S, Denavit-Saubié M, Siggins GR (1988) Somatostatin depresses excitability in neurons of the solitary tract complex through hyperpolarization and augmentation of $I_{\mathrm{M}}$, a non-inactivating voltage-dependent outward current blocked by muscarinic agonists. Proc Natl Acad Sci USA 85:948-952.

Lazareno S, Roberts FF (1989) Functional and binding studies with muscarinic $\mathrm{M}_{2}$-subtype selective antagonists. Br J Pharmacol 98:309317.

Marrion NV, Smart TG, Marsh SJ, Brown DA (1989) Muscarinic suppression of the M-current in the rat sympathetic ganglion is mediated by receptors of the $\mathbf{M}_{1}$-subtype. Br J Pharmacol 98:557-573.

Mash DC, Potter LT (1986) Autoradiographic localization of $M_{1}$ and $\mathbf{M}_{2}$ muscarinic receptors in the rat brain. Neuroscience 19:551-564.

Matsuda H, Stanfield PR (1990) Single inwardly rectifying potassium channels in cultured muscle cells from rat and mouse. J Physiol (Lond) 414:111-124.

Mayer ML, Westbrook GL (1983) A voltage clamp analysis of inward (anomalous) rectification in mouse spinal sensory ganglion neurones. J Physiol (Lond) 340:19-45.

McCormick DA (1989) Acetylcholine: distribution, receptors and actions. Semin Neurosci 1:91-102.

McCormick DA, Pape H-C (1988) Acetylcholine inhibits identified interneurons in the cat lateral geniculate nucleus. Nature 334:246248.

McCormick DA, Prince DA (1986) Acetylcholine induces burst firing in nucleus reticularis neurons by activating a potassium conductance. Nature 319:402-405. 
McKinney M, Anderson D, Forray C, El-Fakahany EE (1989a) Characterization of the striatal $\mathrm{M}_{2}$ muscarinic receptor mediating inhibition of cyclic AMP using selective antagonists: a comparison with the brainstem $\mathrm{M}_{2}$ receptor. J Pharmacol Exp Ther 250:565-572.

McKinney M, Anderson D, Vella-Rountree L (1989b) Different agonist-receptor active conformations for rat brain $\mathrm{M}_{1}$ and $\mathrm{M}_{2}$ muscarinic receptors that are separately coupled to two biochemical effector systems. Mol Pharmacol 35:39-47.

Mihira S, North RA, Surprenant A (1987) Somatostatin increases an inwardly rectifying potassium conductance in guinea-pig submucous plexus neurones. J Physiol (Lond) 390:335-355.

Noma A, Trautwein W (1978) Relaxation of the acetylcholine-induced potassium current in the rabbit sinoatrial node cell. Pfluegers Arch 377:193-200.

North RA (1989) Drug receptors and inhibition of nerve cells. Br J Pharmacol 98:13-28.

North RA, Uchimura N (1989) 5-Hydroxytryptamine acts at 5HT receptors to decrease potassium conductance in rat nucleus accumbens neurones. J Physiol (Lond) 417:1-12.

North RA, Slack BE, Surprenant A (1985) Muscarinic $M_{1}$ and $M_{2}$ receptors mediate depolarization and presynaptic inhibition in guinea-pig enteric nervous system. J Physiol (Lond) 368:435-452.

North RA, Williams JT, Surprenant A, Christie MJ (1987) Mu and delta receptors both belong to a family of receptors which couple to a potassium conductance. Proc Natl Acad Sci USA 84:5487-5491.

Osmanovic SS, Shefner SA (1987) Anomalous rectification in rat locus coeruleus neurons. Brain Res 417:161-166.

Pape HC, McCormick DA (1989) Norepinephrine and serotonin selectivity modulate thalamic burst firing by enhancing a hyperpolarization-activated cation current. Nature 340:715-717.

Potter LT, Ferrendelli CA (1989) Affinities of different cholinergic agonists for the high and low affinity states of hippocampal $\mathbf{M}_{1}$ muscarine receptors. J Pharmacol Exp Ther 248:974-978.

Sakmann B, Trube G (1984) Conductance properties of single inwardly rectifying potassium channels in ventricular cells from guinea-pig heart. J Physiol (Lond) 347:641-657.

Sakmann B, Noma A, Trautwein W (1983) Acetylcholine activation of single muscarinic $\mathrm{K}^{+}$channels in isolated pacemaker cells of the mammalian heart. Nature 303:250-253.

Selyanko AA, Smith PA, Zidichouski JA (1990) Effects of muscarine and adrenaline on neurones from Rana pipiens sympathetic ganglia. J Physiol (Lond) 425:471-500.
Standen NB, Stanfield PR (1978) A potential- and time-dependent blockade of inward rectification in frog skeletal muscle fibres by barium and strontium ions. J Physiol (Lond) 280:169-191.

Stanfield PR, Nakajima Y, Yamaguchi K (1985) Substance P raises neuronal membrane excitability by reducing inward rectification. $\mathrm{Na}$ ture 315:498-501.

Steriade M, McCarley RW (1990) Brainstem control of wakefulness and sleep. New York: Plenum.

Stevens DR, McCarley RW, Greene RW (1991) 5-HT 1 and 5-HT receptors hyperpolarize and depolarize separate populations of medial pontine reticular formation neurons in vitro. Neuroscience, in press.

Surprenant A, North RA (1988) Mechanism of synaptic inhibition by noradrenaline acting at $\alpha_{2}$-adrenoceptors. Proc R Soc Lond [Biol] 234: $85-114$

Swann JW, Carpenter DO (1975) Organisation of receptors for ncurotransmitters on Aplysia neurones. Nature 258:751-754.

Tatsumi H, Costa M, Schimerlik M, North RA (1990) Potassium conductance increased by noradrenaline, opioids, somatostatin, and G-proteins: whole-cell recording from guinea pig submucous neurons. J Neurosci 10:1675-1682.

Irussell LO, Jackson MB (1985) Adenosine-activated potassium conductance in cultured striatal neurons. Proc Natl Acad Sci USA 82: 4857-4861.

Vanderberg CA (1987) Inward rectification of a potassium channel in cardiac ventricular cells depends on internal magnesium ions. Proc Natl Acad Sci USA 84:2560-2564.

Velazquez-Moctezuma J, Gillin JC, Shiromani PJ (1989) Effect of specific $M_{1}$ and $M_{2}$ muscarinic receptor agonists on REM sleep generation. Brain Res 503:128-131.

Williams JT, Henderson G, North RA (1985) Characterization of alpha $a_{2}$-adrenoceptors which increase potassium conductance in rat locus coeruleus neurones. Neuroscience 14:95-101.

Williams JT, Colmers WF, Pan ZZ (1988a) Voltage- and ligand-activated inwardly rectifying currents in dorsal raphe neurons in vitro. J Neurosci 8:3499-3506.

Williams JT, North RA, Tokimasa T (1988b) Inward rectification of resting and opiate-activated potassium currents in rat locus coeruleus neurons. J Neurosci 8:4299-4306.

Yakel JL, Trussell LO, Jackson MB (1988) Three serotonin responses in cultured mouse hippocampal and striatal neurons. J Neurosci 8: 1273-1285. 